TECHNICAL SCIENCES AND TECHNOLOGIES

$U D C 621.8$

DOI: $10.25140 / 2411-5363-2019-3(17)-89-95$

\title{
Jan Semjon, Rastislav Demko \\ PROPOSAL OF HANDLING PROCESS ON ROBOTIZED WORKPLACE WITH DUAL ARM ROBOT
}

Urgency of the research. Deployment of two-arm robots in different plants increases production or assembly efficiency. By designing a robotized workstation for assembly we will improve students' competences in the field of robot programming. By preparing students at robotic workplaces using two-arm robots, we increase their employment in the labor market.

Target setting. The aim of the solution is to design an educational workplace for assembly, equipped with a two-arm robot. The object gripper uses Schunk electric grippers to adjust the range of movement and clamping force. This will allow students to create an optimal program according to individual requirements.

Actual scientific researches and issues analysis. The question of the use of collaborative robotics in industry is highly relevant. If two-arm industrial robots are equipped with safety sensors, we can increase the safety of working in collaborative workplaces without using a collaborative robot.

Uninvestigated parts of general matters defining. Increasing the skills of students in the programming of industrial robots, improves their possibilities of employment in practice. At the same time, it creates conditions for maintaining the growth of the national economy in the near future.

The research objective. The aim of the research was to design a robotic workplace so that students could use a creative approach to solve a given problem. At the same time, the use of the Faculty logo as a model for the proposed assembly preparation will increase the social awareness of the whole university.

The statement of basic materials. The deployment of two-arm robots and the preparation of workers for their programming, maintenance and operation will ensure the development of robotics and facilitate manual work. This also leads to an increase in the share of production and deployment of products with higher added value.

Conclusions. The article describes the design, production, programming and commissioning of a robotized workplace for educational purposes. The workplace is equipped with a two-arm Yaskawa robot and a pair of Schunk electric grippers. The aim of the work was to design an assembly and dismantling process that would demonstrate the possibilities of working on a two-arm robot. The robotized workstation, when completed, allows the rotary cylinder to be inserted and then removed in a closed loop. Manipulated parts are found in the proposed fixtures, whose shape is based on the university's initial fonts, which make up its logo. Students participating in the learning process will be able to modify the program based on the teacher's assignment and thus improve their robot programming skills.

Keywords: robot; programming; education; logo.

Fig.: 7. Table: 1. References: 11.

Urgency of the research. Deployment of two-arm robots in different plants increases production or assembly efficiency. By designing a robotized workstation for assembly we will improve students' competences in the field of robot programming.

Target setting. The aim of the solution is to design an educational workplace for assembly, equipped with a two-arm robot. The object gripper uses Schunk electric grippers to adjust the range of movement and clamping force. This will allow students to create an optimal program according to individual requirements.

Actual scientific researches and issues analysis. An industrial robot is part of a robotic system used to make various components. Such a robot is autonomous, programmable and capable of moving in three or more axis. The industrial robot is used for stereotypical and repetitive work in which man would not be fully utilized. Typical applications of these robots include welding, spraying, handling, assembly, etc. Industrial robots and production automation have brought many benefits to industrial production. The most important benefit of robots is their efficiency, and they can work at a higher speed than a manual working man. If the robot is properly programmed, it can work without interruption and thus massively increase production and reduce the number of failed products [1]. Although the initial investment is high, they can turn this investment into profit in a relatively short time. Thanks to their efficiency, consistency and price reduction, they are gaining popularity with parts manufacturers for various industries. The market for industrial robots is large and growing, especially in less developed countries. Technology is constantly changing, so it is difficult to keep up with the rapidly changing changes in this area [2;3]. The largest share of the robot market is in: China, Japan, South Korea, US and Germany.

(c) Семйон Ян, Демко Растіслав, 2019 
TECHNICAL SCIENCES AND TECHNOLOGIES

The robot we use for assembly activities is the robot of the company Motoman Yaskawa, with the designation SDA 10F. It is a two-arm robot that has 15 rotary joints - 7 rotary joints for each hand and 1 axis base rotation. It has high agility and freedom of movement on a small ground plan. Due to its dexterity and its large number of joints, it is most often used for assembly, handling and operator of machines, packaging operations or other work that is mostly performed by people [4].

Base parameters robot SDA 10F are shown in Table 1.

Table 1

Yaskawa robot parameters [5]

\begin{tabular}{|l|c|}
\hline Weight & $220 \mathrm{~kg}$ \\
\hline Payload & $2 \times 10 \mathrm{~kg}$ \\
\hline Horizontal /Vertical Reach & $720 / 1440 \mathrm{~mm}$ \\
\hline Speed & $130-400^{\circ} / \mathrm{s}$ \\
\hline Repeatability & $+/-0.1 \mathrm{~mm}$ \\
\hline
\end{tabular}

Current status in workplace. At present, the SDA 10F was mainly used for demonstrations for visits and the teaching process (Fig. 1). Students learned to create a program in which it was necessary to simultaneously use two arms fitted with electric grippers in the handling process. Used grippers are from company Schunk, the first gripper is the PG 70, which is equipped with two fingers moving parallel [6]. The second gripper is labelled EZN 64 and uses three fingers that are $120^{\circ}$ rotated relative to each other [7]. The two-finger gripper is suitable for gripping non-rotating or rotating objects beyond the outer surface. The three-finger gripper is designed to hold objects behind the inner circular hole, where the ability to centre the object of manipulation can be used. Figure 1shows the present workstation with the SDA 10F robot, a pair of grippers and an angled stack of parts that uses gravity to position the pipes of dimension 50x100 $\mathrm{mm}$ [8].

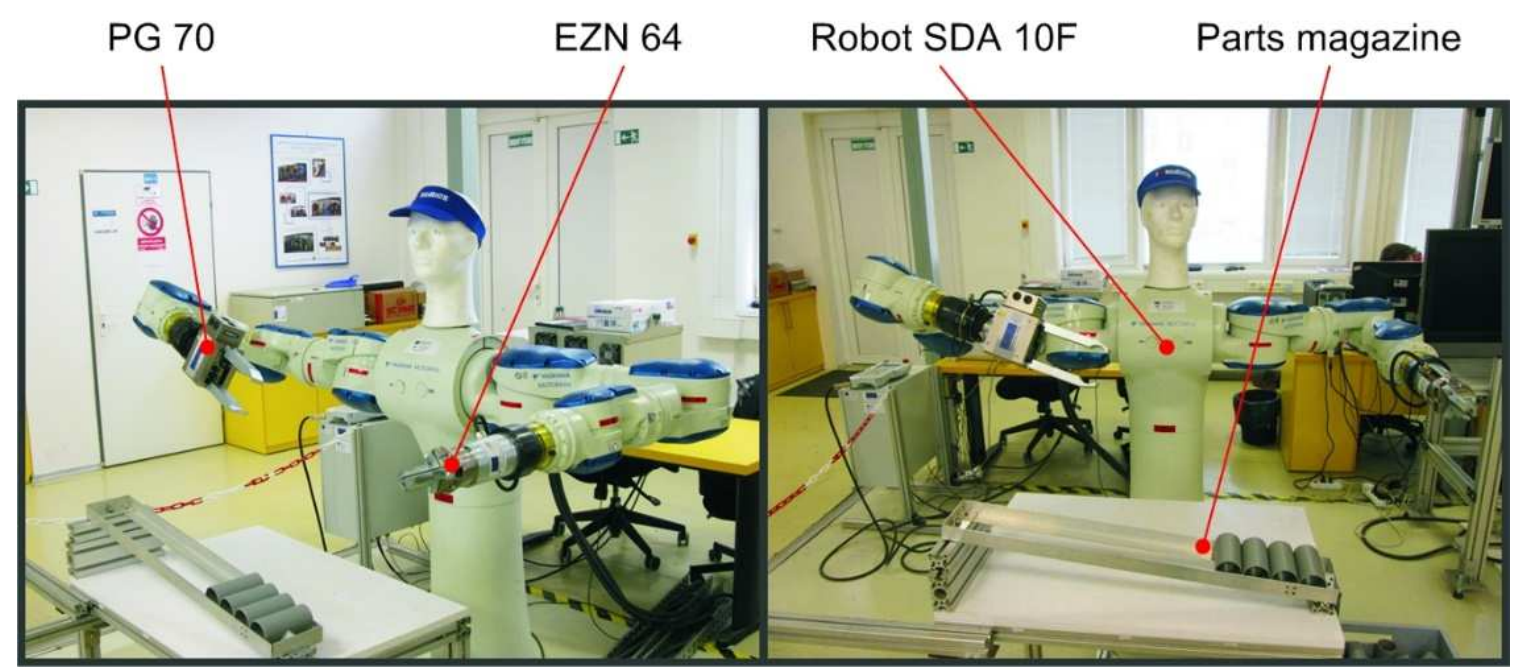

Fig. 1. Ground plan of the workplace

Most high school students, as well as domestic and foreign visits to the Institute of Automation, Mechatronics, Robotics and Production Technology at the Technical University in Kosice (TUKE), do not know the logo of our university. That is why we used this logo as a basis for creating two mounting fixtures for storing manipulated parts. It is about integrating the TUKE logo into the working environment of the robot and at the same time getting the logo into the students' subconscious. It will also help with excursions or demonstrations to students interested in robotics.

Proposal of robotized workplace. Since the robot has already been programmed to perform an action where it moves the rollers on an inclined plane in an infinite loop, (Fig. 2) we will not interfere in this program. We try to keep the created program in order to keep it working if it 
TECHNICAL SCIENCES AND TECHNOLOGIES

needs to be used to illustrate the work of the robot. For this reason, we have defined a new working area where the proposed manipulated process will be implemented. The new $400 \times 700 \mathrm{~mm}$ work surface is located on the right side of the anchored robot. This means that if we want to implement programming and demonstration of the robot work it is necessary to move the robot to the new starting position, according to fig. 2 by rotating the robot's torso $90^{\circ}$ clockwise.

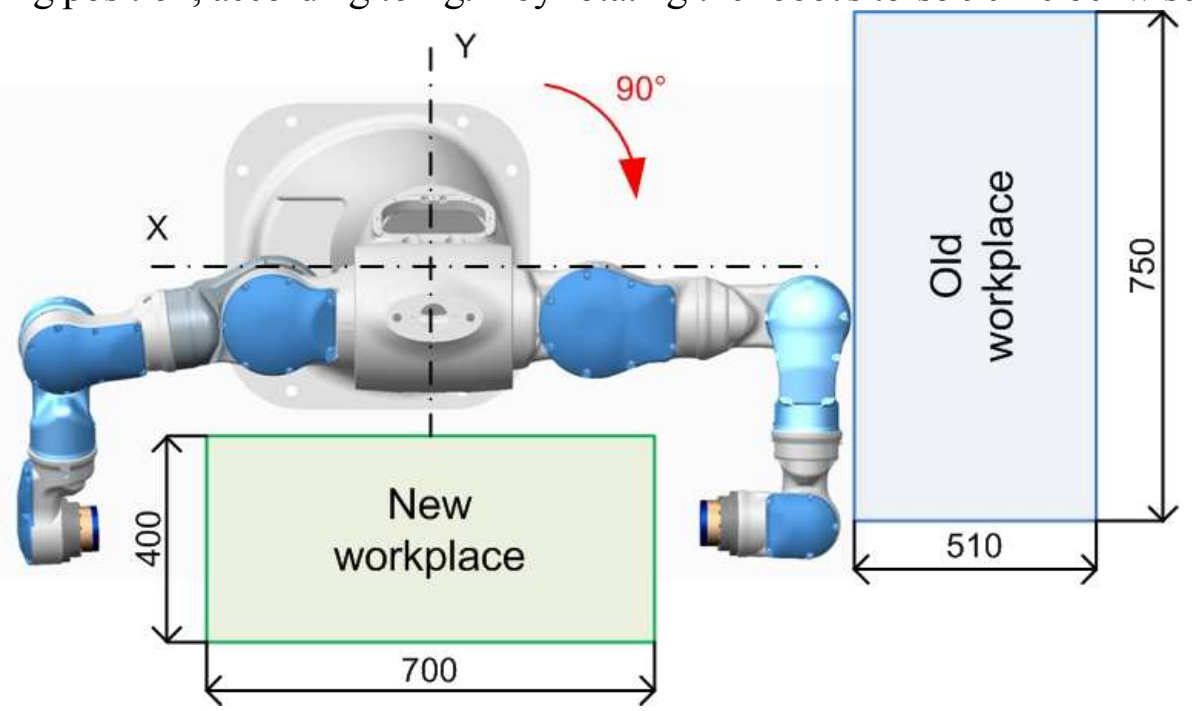

Fig. 2. Robot in new working position

For the new work area it was necessary to design and produce a workbench whose height from the ground was $560 \mathrm{~mm}$ and the table size was 390x690 $\mathrm{mm}$. The table is made with Bosch system aluminum profiles $50 \times 50 \mathrm{~mm}$. On the top of the table there is a white $16 \mathrm{~mm}$ thick laminated board in which holes are made to hold the fixtures.

The preparations are made of stainless steel sheets $1.5 \mathrm{~mm}$ thick and $208 \times 253 \mathrm{~mm}$ in size. When designing the preparations we used the university logos, which consist of two letters "TU" and the following shape (Fig. 3).
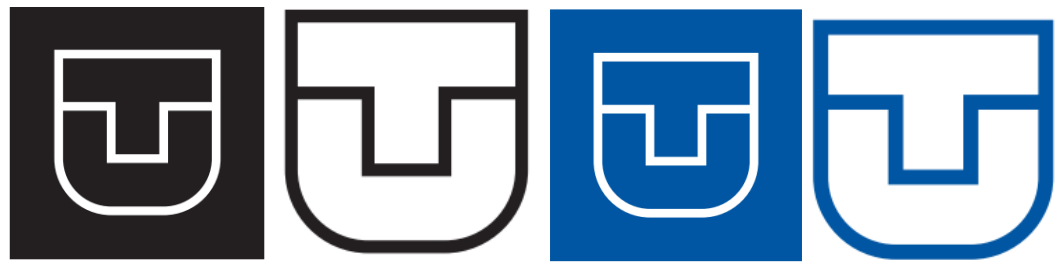

Fig. 3. Logo Technical University of Kosice/Faculty of Mechanical Engineering

Holes are provided at the edges of the plates to attach the M5 threaded rods. The first sheet has a "T" shaped hole and the second sheet a shape "U". On individual metal sheets are subsequently glued two letters, made of blue self-adhesive film which also forms the letters "TU". The blue color was chosen deliberately, as the logo of the Faculty of Mechanical Engineering of the Technical University of Kosice, where our workplace also belongs, is also blue [9].

The resulting shape of the proposed fixture consisting of two draw-off points located on the work table and it's shown in (Fig. 4). To the left side mounting fixtures (T-shaped cut out), it is possible to place a maximum of 5 cylindrical parts. Into the right side the mounting fixture (U-shaped cut out), it is possible to place until 7 cylindrical parts. In the case of teaching with the use of these fixtures, it is possible for the teacher to determine how many pieces cylindrical parts will be needed to create the program. In addition to the number of parts, the teacher can determine their location as well as the direction of collection and storage. This leads to multiple combinations, allowing each student to enter an individual assignment. 
TECHNICAL SCIENCES AND TECHNOLOGIES

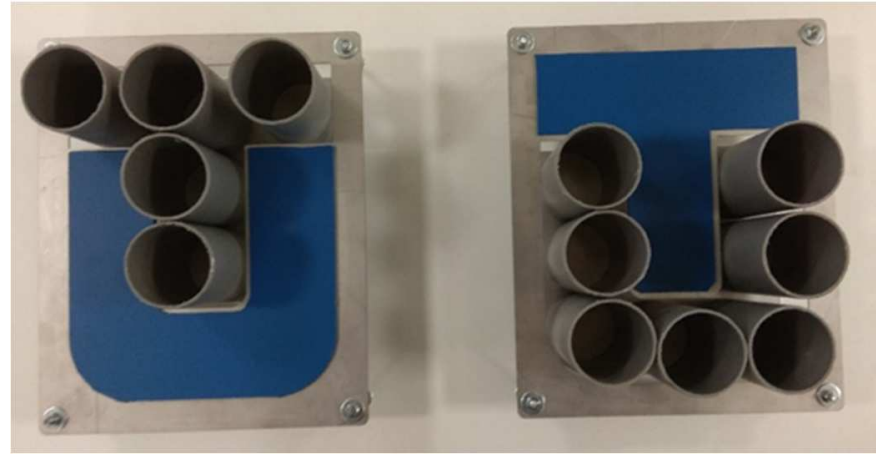

Fig. 4. The resulting face of the product being made

Creating a sample program on the robot. After switching on the control unit and the proper involvement of the pendant, after a while, the main menu on the pendant will start. In the menu, we are particularly interested in the "Job" section, where we can see existing programs, delete programs or create your own, new programs. When selecting "Create new job" we will open a window where we can create and name our own, new program. The display is touch-sensitive, so it's easier to move around. This is most useful especially when writing and then pressing the ENTER button. If we have created a program it is necessary to change the control of the robot arms in the "Control Group" item so that we can move both arms at the same time. In our program we have to see the designation "R1 + R2: R1". In (Fig. 5) is a sample of the program, where a red box indicates a label that indicates that we can use both robot arms in the program [10].

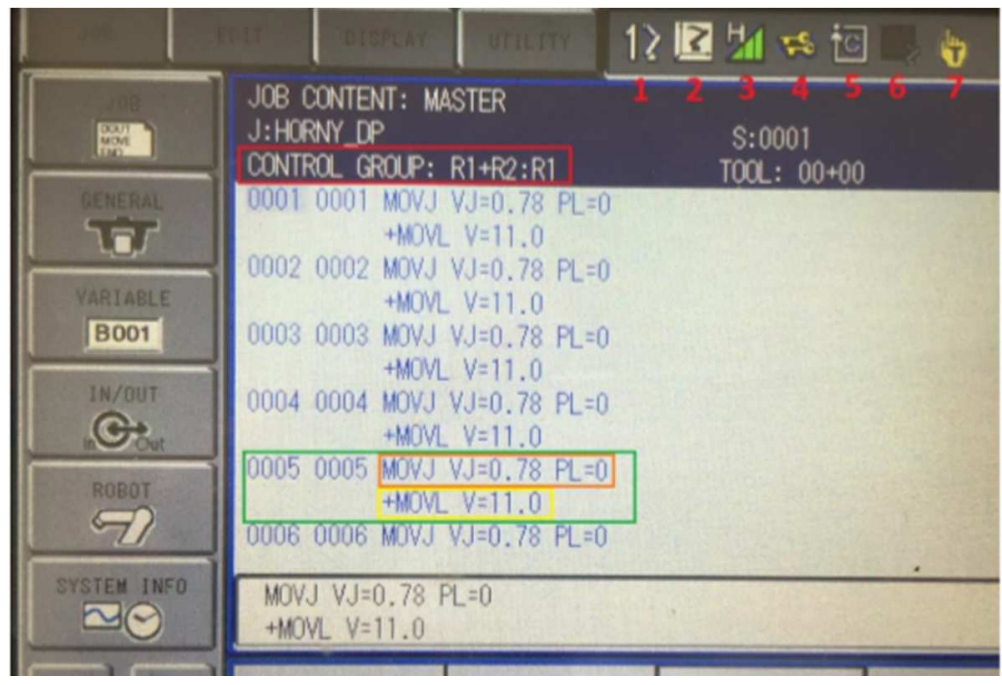

Fig. 5. Demonstration of the program on pendant by robot

The row with the numeric labels at the top represents the robot's status bar. First (1) the currently used robot arm is shown. Switching between robot arms, using the "ROBOT" button. The second (2) is the currently used coordinate system, which is the axis coordinate system. To switch between coordinate systems, press the "COORD" button. Next (3) we can see the speed of the robot, currently set to "High". Another icon (4) symbolizes the user level. Whether it is an operator, programmer or service worker. At each level we can adjust something else, we have other privileges.

The number 5 icon is the play mode: step cycle or continuous mode. We use them to see how the program works.

The penultimate icon shows what the manipulator is doing. It also shows an alarm or an emergency stop. The last icon tells us which mode we use [11]. Either it is manual or automatic. In manual mode, we can control the robot with a pendant. In automatic mode, the program works separately. One line of the program is shown in green. This line contains code for both 
TECHNICAL SCIENCES AND TECHNOLOGIES

arms marked orange and yellow. "MOVJ" represents the rotational movement of the individual joints, "MOVL" is a linear motion along a line, "VJ" is a motion speed that ranges from 0$100 \%$. Currently, the speed is set to $0.78 \%$ for one arm and $11 \%$ for the other arm. The basic position at the beginning of the program as well as the overall view of the workplace can be seen in (Fig. 6). It is the position that the robot always takes when starting the program.

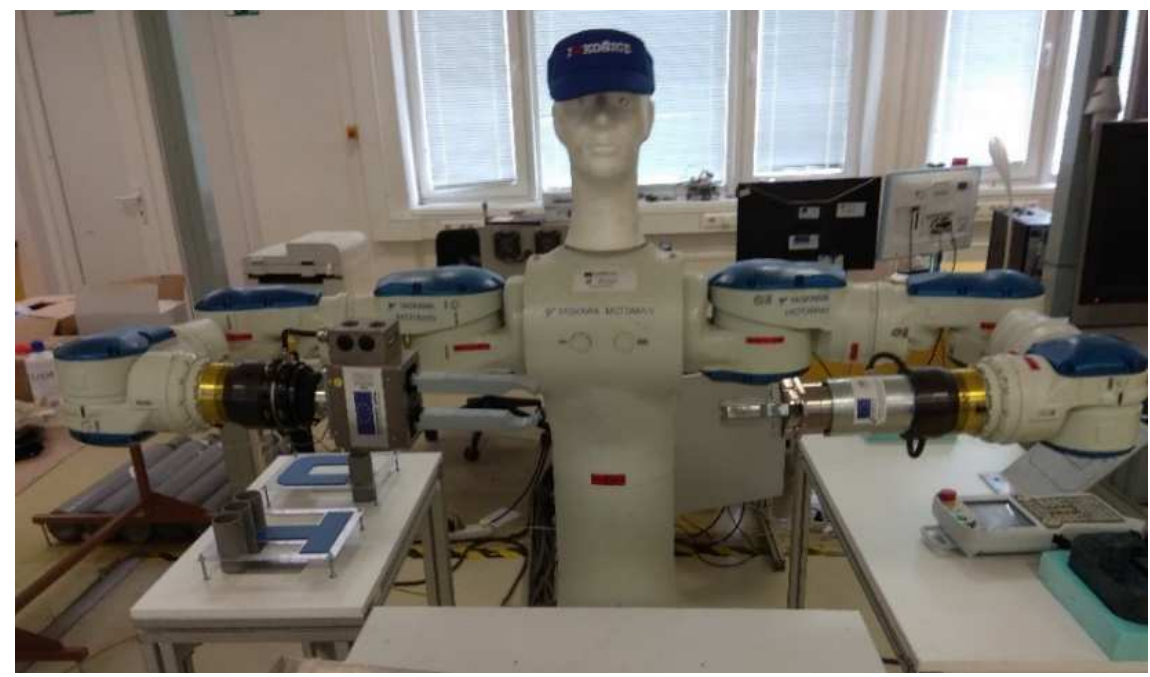

Fig. 6. The starting position of the robot

Then the robot turns 90 degrees and begins to take the rollers out of the cut-out "U" with a 3 -point grip. Subsequently, he folds the roller into the second gripper and places it in the logo with the letter "T" cut out, (Fig. 7).
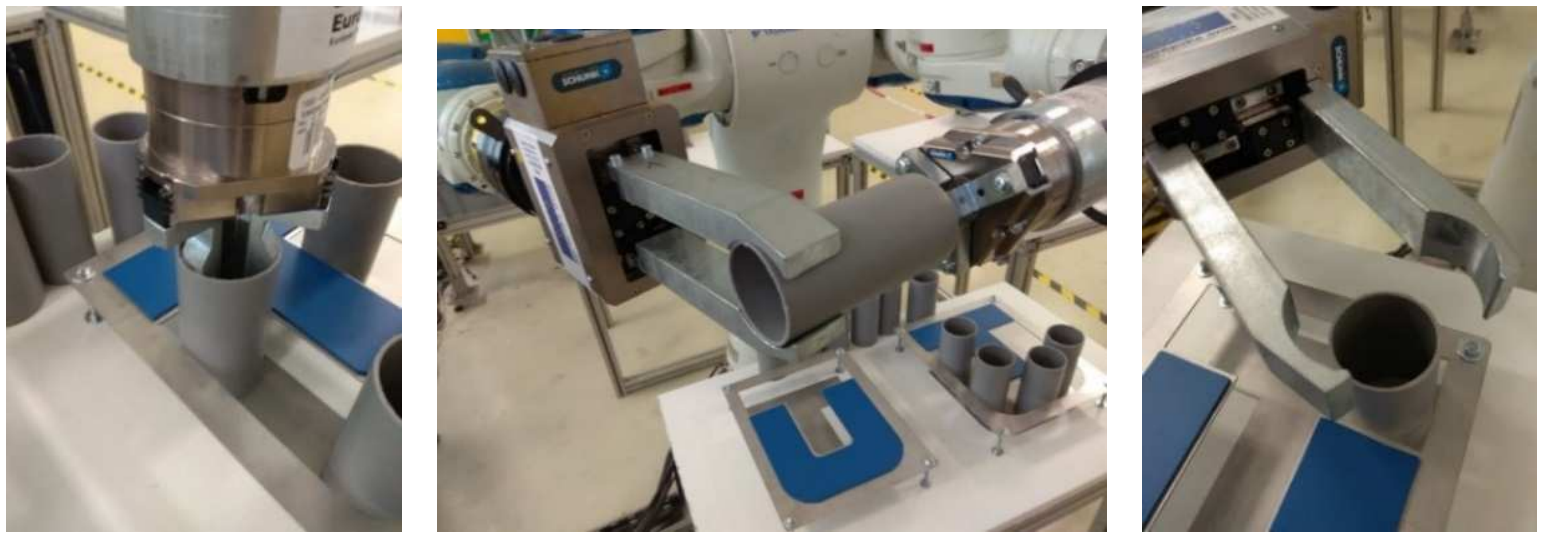

Fig. 7. Removing and inserting parts

Conclusions. The design and implementation of a new part of the robotized workplace was intended to improve and optimize the learning process with the SDA 10F double-arm robot. The proposed solution created the prerequisite for assigning individual tasks to students during the semester. The role of the teacher has turned into a consultant who leads students to create a program on the robot. The result is increased student competence and self-esteem, which can be used in practice. The financial intensity of the solution was around $€ 50$, as most of components were from by the Department of Robotics, which is also a teaching workplace. The secondary benefit is the possibility of using the proposed workplace for presentation tasks. Over the course of the academic year, over 200 students and school staff attend various field trips at the Industrial Robotics Laboratory, leading to faculty and university visibility.

Acknowledgement. This article was created thanks to the VEGA project support: 1/0389/18 Research and development of cinematically redundant mechanisms. 


\section{References}

1. Vagas, M., Balaz, V., Semjon, J., Putala, J. (2016). Methodological process for creation of palletizing - assembly workplace. Technical sciences and technologies: Scientific journal. Vol. 6, no. 4, p. 189-193, ISSN 2411-5363.

2. Semjon, J., Kostka, J., Mako, P. (2019). Návrh a optimalizácia robotizovanej výrobnej linky. ATP journal: priemyselná automatizácia a informatika. Bratislava (Slovensko): HMH Roč. 26, č. 4, s. 44-46. ISSN 1335-2237, [in Slovak].

3. Semjon, J. (2018). Design of robotised workstation for handling concrete products. Scientific Letters of Academic Society of Michal Baludansky. Košice (Slovensko), Roč. 6, č. 6A, s. 90-94, ISSN 1338-9432, [in Slovak].

4. Yaskawa. Retrieved from https://www.motoman.com/en-us/products/robots/industrial/assemblyhandling/sda-series/sda10d.

5. Yaskawa. Retrieved from https://www.yaskawa.eu.com/index.php?eID=dumpFile\&t $=\mathrm{f} \& \mathrm{f}=$ 11546\&token=0ae89d4b680b5867c1e 0cda552dfc6eff9ce3529.

6. Schunk. Retrieved from https://schunk.com/de_en/gripping-systems/series/ezn/.

7. Schunk. Retrieved from https://schunk.com/sk_sk/uchopovacie-systemy/product/24930306095-pg-70/.

8. Vagas, M. (2017). Metodika navrhovania robotizovaného pracoviska pre paletizáciu. Automatizácia a robotika v 21. storočí. - Košice : TU, s. 38-43, ISBN 978-80-553-2820-1, [in Slovak].

9. TUKE. Retrieved from http://www.tuke.sk/wps/wcm/connect/d4178da6-0e7f-43f4-8548$85 \mathrm{c} 39 \mathrm{e} 208 \mathrm{fdd} /$ dizajn_manual_tuke_1_cast.pdf?MOD=AJPERES\&CVID $=\mathrm{mC} C \mathrm{CTeg} \& \mathrm{CVID}=\mathrm{mC} 0 \mathrm{CT}$ eg\&CVID $=$ mC0CTeg.

10. Sukop, M., et al. (2017). Robot ABB IRB 360 applications in the learning process. Journal of Automation and Control. Vol. 5, no. 2, p. 73-75, ISSN 2372-3033.

11. Balaz, V., Vagas, M. (2017). Programming of robots for education of teachers at secondary vocational schools in CAD systems. Journal of Technology and Exploitation in Mechanical Engineering. Vol. 3, no. 2, p. 12-16, ISSN 2451-148X.

УДК 621.8

\section{Ян Семйон, Растіслав Демко}

\section{ПРОЕКТУВАННЯ РОБОТИЗОВАНОЇ РОБОЧОЇ СТАНЦЇ̈ НА БАЗІ РОБОТА 3 ДВОМА МЕХАНІЧНИМИ РУКАМИ}

Актуальність теми дослідження. Використання роботів з двома механізованими руками на різних заводах підвищує ефективність виробництва або складання. Розробка роботизованої робочої станиії підвищує компетентність студентів у галузі програмування роботів. Проведення занять для студентів на робочих місиях, оснащених дворукими роботами, збільщує їх зайнятість на ринку праиі.

Постановка проблеми. Необхідно розробити навчальне робоче місие для складання, обладнане роботом з двома механізованими руками. Захоплення об'єкта здійснюється електричними захватами Schunк, можливе регулювання сили затискання. Це дозволить навчитись студентам створювати оптимальну програму роботи робота відповідно до індивідуальних вимог.

Аналіз останніх досліджень $і$ публікацій. Питання про використання робототехніки у промисловості є дуже актуальним. Оснащення промислових роботів з двома механізованими руками спечіальними датчиками, підвищує безпеку роботи на робочих місиях, де одночасно прачює декілька роботів.

Виділення недосліджених частин загальної проблеми. Підвищення кваліфікаиії студентів з програмування промислових роботів, покращує їх можливості прачевлаштування. Водночас ие створює умови для підтримки зростання начіональної економіки у найближчому майбутньому.

Постановка завдання. Метою дослідження є розробка робота, щоб студенти мали можливість використовувати творчий підхід для вирішення заданої проблеми. У той же час використання логотипу факультету у якості моделі для складання збільшить соціальну обізнаність усього університету.

Виклад основного матеріалу. Розповсюдження дворуких роботів та підготовка прачівників до їх програмування, обслуговування та експлуатації забезпечать розвиток робототехніки та полегшить ручну роботу. Це також сприятиме збільшенню частки виробництва та розміщенню продукиії з більш високою доданою вартістю.

Висновки відповідно до статті. У статті описано проектування, виробнищтво, програмування та введення в експлуатацію роботизованого робочого місия для освітніх иілей. Робоче місие оснащене дворуким роботом Үаskаша та парою електричних захватів Schunk. Метою роботи є розробка прочесу складання та демонтажу, який би демонстрував можливості роботи дворуких роботів. Роботизована робоча станиія дозволяє здійснювати програмування роботів на виконання послідовних дій, наприклад, вставити поворотний циліндр і потім вийнятти його в закритому циклі. У якості робочого простору дворукого роботу використовуються спеціальні шаблони, форма яких заснована на початкових шрифтах універси- 


\section{TECHNICAL SCIENCES AND TECHNOLOGIES}

тету, які складають його логотип. Студенти, які беруть участь у навчальному процесі, зможуть модифікувати програму на основі завдання вчителя та таким чином вдосконалити свої навички роботи з роботизованими станціями.

Ключові слова: робот; програмування; освіта; логотип.

Рис.: 7. Таблиия: 1. Бібл.: 11.

Semjon Ján - PhD in Technical Sciences, Associate Professor,Technical University of Kosice, Faculty of Mechanical Engineering, Department of Robotics (Park Komenskeho 8, 04200 Kosice, Slovak Republic).

Семйон Ян - кандидат технічних наук, доцент, Технічний університет Кошице, Механічний факультет, Кафедра робототехніки (Park Komenskeho 8, 04200 Kosice, Slovak Republic).

E-mail: jan.semjon@tuke.sk

SCOPUS Author ID: 55571411200

Demko Rastislav - PhD student, Technical University of Kosice, Faculty of Mechanical Engineering, Department of Robotics (Park Komenskeho 8, 04200 Kosice, Slovak Republic).

Демко Растіслав - аспірант, Технічний університет Кошице, Механічний факультет, Кафедра робототехніки

(Park Komenskeho 8, 04200 Kosice, Slovak Republic).

E-mail: rastislav.demko.student@tuke.sk 